\title{
REKOGNISI DAN DAMPAK KEPEMIMPINAN INSTRUKSIONAL KEPALA MADRASAH
}

\author{
Alfian Erwinsyah ${ }^{1}$, Hasyim Mahmud Wantu ${ }^{2}$, Asriyati Nadjamuddin ${ }^{3}$ \\ ${ }^{123}$ Institut Agama Islam Negeri Sultan Amai Gorontalo \\ Email: alfian_erwinsyah@iaingorontalo.ac.id
}

\begin{abstract}
ABSTRAK
Umumnya kepala madrasah hanya fokus dengan tugas administratif yang ketat dibandingkan berperan sebagai Pemimpin Instruksional. Semestinya kepala madrasah memberikan aksi untuk meningkatkan pembelajaran kepada siswa. Serta, kepala madrasah harus memprioritaskan kualitas pengajaran untuk mewujudkan visi madrasah. Tujuan penelitian ini adalah untuk menguraikan temuan studi empiris, mengeksplorasi praktik kepemimpinan instruksional Kepala Madrasah Ibtidaiyyah Kabupaten Gorontalo. selama masa pandemic covid-19. Desain penelitian kualitatif digunakan dan wawancara semi-terstruktur dilakukan dengan 11 kepala madrasah ibtidaiyyah di Kabupaten Gorontalo, ditambah dengan pengisian angket secara online. Awalnya data dianalisis secara induktif dan berturut-turut diberi kode untuk menghasilkan temuan dan kesimpulan. Hasil penelitian menunjukkan bahwa kepala Madrasah Ibtidaiyyah Kabupaten Gorontalo secara keseluruhan memahami dan mendefinisikan tugas-tugas yang berkaitan dengan pengembangan praktik pembelajaran. Khususnya mengenai supervisi guru, bagaimana mereka memantau dan mengevaluasi pengajaran baik luring maupun daring, serta ditemukan pula bahwa kurang lebih kewajiban dan pencapaian yang terkait dengan menjadi kepala Madrasah Ibtidaiyyah di Kabupaten Gorontalo sebagian besar sesuai dengan praktik kepemimpinan instruksional bahkan tanpa memiliki pengetahuan dan pengakuan atas nama kepemimpinan instruksional. Pemantauan dan pengawasan pembelajaran yang dikombinasikan dengan pembelajaran profesional terkemuka sangat ditandai dalam data. Ada keinginan kebijakan yang kuat, yang dijelaskan dalam Kebijakan Pendidikan Nasional bahwa kepala Madrasah bertanggung jawab atas peningkatan mutu secara keseluruhan di Madrasah dan seharusnya menjadi pemimpin pembelajaran.
\end{abstract}

Kata Kunci: Kepemimpinan Instruksional, Kepala madrasah, Pembelajaran Siswa.

\begin{abstract}
Generally, madrasah principals only focus on strict administrative duties rather than acting as Instructional Leaders. The principal of madrasah should take action to improve learning for students. Also, the principal must prioritize the quality of teaching to realize the vision of the madrasah. The purpose of this study was to describe the findings of an empirical study, exploring the instructional leadership practices of the Principal of Madrasah Ibtidaiyyah Gorontalo District. during the covid-19 pandemic. A qualitative research design was used and semi-structured interviews were conducted with 11 principals of madrasah ibtidaiyyah in Gorontalo District, plus filling out an online questionnaire. Initially data were analyzed inductively and successively coded to produce findings and conclusions. The results showed that the head of Madrasah Ibtidaiyyah Gorontalo District as a whole understands and defines tasks related to the development of learning practices. In particular regarding teacher supervision, how they monitor and evaluate teaching both offline and online, and it was also found that more or less the
\end{abstract}


obligations and achievements associated with being the head of Madrasah Ibtidaiyyah in Gorontalo District are mostly in accordance with instructional leadership practices even without having knowledge and recognition on behalf of instructional leadership. Learning monitoring and supervision combined with leading professional learning is highly marked in the data. There is a strong policy desire, which makes it clear in the National Education Policy that Madrasah principals are responsible for overall quality improvement in Madrasahs and should be learning leaders.

Keywords: Instructional Leadership, Principal of madrasah, student learning.

\section{PENDAHULUAN}

Sudah menjadi fakta umum bahwa kepemimpinan Madrasah merupakan faktor kunci dan sentral dalam peningkatan kinerja Madrasah. Secara internasional maupun nasional, fakta menunjukkan bahwa kepemimpinan dalam lembaga pendidikan sebagai indikator utama untuk meningkatkan kinerja serta prestasi peserta didik. ${ }^{1}$

Kepemimpinan Instruksional atau Pemimpin Pengajaran berbeda dari tugas kepala sekolah sebagai pengatur atau manejer dalam banyak hal. Para kepala sekolah yang membanggakan diri mereka sebagai manejer, biasanya terlalu fokus dengan tugas- tugas administratif yang ketat dibandingkan dengan kepala sekolah yang berperan sebagai Pemimpin Instruksional. Peran yang terakhir melibatkan penentuan tujuan-tujuan (goals) yang jelas, pengalokasian sumberdaya untuk pengajaran (instruction), pengurusan kurikulum, pemantauan rencana pembelajaran (lesson plans), dan evaluasi para guru. Singkat kata, kepemimpinan instruksional adalah aksi-aksi yang seorang kepala sekolah lakukan, atau delegasikan kepada orang lain, untuk meningkatkan pembelajaran siswa. Sebaliknya, Pemimpin Instruksional memprioritas atau mengutamakan kualitas pengajaran sebagai prioritas utama sekolah dan berusaha untuk mewujudkan visi itu menjadi kenyataan. ${ }^{2}$

Stronge menyatakan untuk memperoleh hasil prestasi siswa yang baik perlu perubahan peran yang dramatis dari seorang kepala sekolah yang fokus pada isu-isu manajerial kepala sekolah yang fokus pada isu-isu pembelajaran (instructional). Moos Johansson dan Day dalam penelitiannya menyatakan kepala sekolah efektif dicirikan memiliki kepemimpinan pembelajaran yang kuat, yang fokus pada pengembangan standar kurikulum, monitoring perkembangan siswa, dan memaksimalkan waktu belajar. ${ }^{3}$

Pendapat dari Harris, bahwa, "It seems that instructional leadership is little more than a shorthand way of describing those leadership influences and

\footnotetext{
${ }^{1}$ Annisa Fortuna Ramadhani, "Kepemimpinan Pendidikan” (2019): 1-133.

${ }^{2}$ Ahmad, Syarwan. "Problematika kurikulum 2013 dan kepemimpinan instruksional kepala sekolah." Jurnal Pencerahan 8.2 (2014).

${ }^{3}$ Sunardi, Sunardi, Piter Joko Nugroho, and Setiawan Setiawan. "Kepemimpinan Instruksional Kepala Sekolah." Equity in Education Journal 1.1 (2019): 20-28.
} 
practice within an organization that impact upon student achievement." Pendapatpendapat para ahli tentang kepemimpinan instruksional pada dasarnya memiliki persamaan, yakni terfokus pada proses dan hasil belajar siswa melalui guru. Perbedaannya hanyalah terletak pada redaksi katanya saja. Berdasarkan pendapat di atas, dapat disimpulkan bahwa kepemimpinan instruksional adalah kepemimpinan yang fokus pada proses dan hasil belajar siswa melalui pemberdayaan guru secara profesional. Hasil penelitian Hammond, et al. ditemukan bahwa ada dua teknik pemimpin mempengaruhi hasil belajar siswa: (1) melibatkan praktik kepemimpinan langsung mempengaruhi pembelajaran; dan (2) melibatkan praktik kepemimpinan tidak langsung mempengaruhi pembelajaran. ${ }^{4}$

Penelitian kepemimpinan pendidikan mengungkapkan bahwa kepemimpinan instruksional adalah salah satu hal yang berpengaruh dan persisten di antara atribut kepemimpinan dalam lembaga pendidikan. Kepemimpinan instruksional dijadikan sebagai model kepemimpinan yang penting dan paten karena memiliki hubungan dan dampak pada Madrasah, guru dan hasil belajar peserta didik. Berbagai bukti empiris dengan jelas menyoroti kualitas kinerja di Madrasah dan pembelajaran pelajar dengan kepemimpinan instruksional. ${ }^{5}$ Penelitian menunjukkan bahwa selama empat dekade terakhir, kepemimpinan instruksional telah diterapkan secara bertahap di seluruh dunia untuk meningkatkan praktik kepemimpinan pendidikan. Praktik-praktik ini berdampak positif pada kualitas pembelajaran peserta didik dan pada akhirnya berdampak pada peningkatan kualitas Madrasah. Penelitian juga menyoroti bahwa salah satu faktor yang berkontribusi terhadap peningkatan hasil peserta didik adalah perilaku pemimpin Madrasah. ${ }^{6}$

Perkembangan awal praktik kepemimpinan instruksional dapat ditelusuri kembali ke akhir 1970-an dan awal 1980-an dengan pengembangan penelitian tentang evaluasi sekolah. Banyak peneliti melakukan penelitian yang berbeda untuk memahami faktor-faktor yang mempengaruhi prestasi peserta didik di berbagai bidang seperti status sosial ekonomi, latar belakang keluarga dan fasilitas di sekolah, kualitas pembelajaran dan banyak parameter terkait prestasi peserta didik. Secara umum, Kepemimpinan atau khususnya kepemimpinan instruksional dibedakan sebagai faktor utama dan vital untuk keberhasilan peserta didik. Kepemimpinan instruksional diwakili dan digambarkan sebagai salah satu elemen untuk membedakan antara sekolah berkinerja tinggi dan

\footnotetext{
${ }^{4}$ Usman, Husaini. "Model kepemimpinan instruksional kepala sekolah." Jurnal Cakrawala Pendidikan 34.3 (2015).

${ }^{5}$ Hermino, A. Kepemimpinan Pendidikan di Era Globalisasi. (Jakarta: Pustaka Pelajar, 2014), h. 45.

${ }^{6}$ Karim, Mukhammad A., and Erni Rosminingsih. "Pengaruh Dimensi Kepemimpinan Instruksional Kepala Sekolah Terhadap Efikasi Diri Guru." Inspiratif Pendidikan 9.2 (2020): 1834.
} 
sekolah berkinerja rendah. ${ }^{7}$ Pemimpin instruksional menetapkan visi dan arah praktik instruksional sekolah, mengkoordinasikan upaya mereka untuk meningkatkan pembelajaran dan hasil belajar peserta didik. Sekolah yang efektif dipandang memiliki visualisasi yang sama, tujuan pengajaran yang jelas, komitmen tujuan akademik, dan budaya. Kemudahan budaya ini tidak hanya untuk belajar tetapi juga membekali peserta didik dengan keyakinan dan norma yang tinggi. Kepemimpinan instruksional memberikan landasan bagi guru untuk meningkatkan kinerja mereka dalam proses belajar mengajar, sehingga memungkinkan peserta didik untuk mencapai hasil yang lebih baik. Singkatnya, pemimpin instruksional yang berorientasi pada tujuan dapat dianggap sebagai katalisator perubahan budaya dalam masyarakat. ${ }^{8}$

Di banyak negara, perkembangan praktik kepemimpinan instruksional masih dalam tahap awal. Hallinger, berpendapat bahwa pengetahuan yang ditemukan tentang kepemimpinan instruksional sudah diatur dengan baik di beberapa negara. Studi pragmatis baru saja mulai muncul belakangan ini di benua-benua seperti Asia, Afrika dan Amerika Latin. Di negara-negara di benua Asia, khususnya di Indonesia informasi tentang studi kepemimpinan dan kinerjanya termasuk studi kepemimpinan instruksional masih sedikit. Data tentang studi kepemimpinan instruksional terus tumbuh dan berkembang pesat, memberikan bukti dari banyak negara dan situasi sehingga memberikan sinyal untuk mengeksplorasi lebih lanjut tentang kekurangan ini ${ }^{9}$.

Penelitian ini bertujuan untuk mengeksplorasi praktik kepemimpinan instruksional di madrasah ibtidaiyyah di Kabupaten Gorontalo. Penelitian ini juga bermaksud untuk mengkaji seperti apa konseptualisasi kepemimpinan instruksional dalam konteks Kabupaten Gorontalo. Studi ini mengeksplorasi praktik kepemimpinan instruksional kepala madrasah ibtidaiyyah di Kabupaten Gorontalo. Informasi tentang kepemimpinan instruksional di Kabupaten Gorontalo secara bertahap meningkat selama bertahun-tahun, meskipun literatur yang tersedia sangat sedikit.

Beberapa informasi latar belakang harus dipertimbangkan berkenaan dengan Peraturan Menteri Agama (PMA) nomor 57 tahun 2017 tentang Kepala Madrasah. Peraturan ini menguraikan tujuan utama untuk meningkatkan dan mengembangkan presentasi dalam sistem pendidikan. Dalam peraturan tersebut disebutkan bahwa semua pimpinan di tingkat Madrasah wajib menjalankan

${ }^{7}$ Djafri, Novianty. Manajemen Kepemimpinan Kepala Sekolah:(Pengetahuan Manajemen, Efektivitas, Kemandirian Keunggulan Bersaing dan Kecerdasan Emosi). Deepublish, 2017.

${ }^{8}$ Cucu Sukmawati and Endang Herawan, "Kepemimpinan Instruksional Kepala Sekolah, Komitmen Guru Dan Mutu Kinerja Mengajar Guru," Jurnal Administrasi Pendidikan 23, no. 2 (2016).

${ }^{9}$ E. Mulyasa, Manajemen Dan Kepemimpinan Kepala Sekolah, 2015. 
fungsi kepemimpinannya masing-masing secara efektif. Di dalamnya memuat hal-hal kepemimpinan organisasi yang berkaitan dengan peningkatan kinerja kelembagaan melalui kegiatan seperti perencanaan strategis, perbaikan kurikulum dan rencana kegiatan ko-kurikuler. Yang terutama adalah kepemimpinan, seperti yang dicantumkan dalam peraturan. Ini mencakup tidak hanya tugas kepala Madrasah tetapi meluas ke mereka yang berhubungan dengan kepemimpinan formal di Madrasah termasuk semua sistem manajemen dari atas ke bawah. Dalam hal menjadi kepala Madrasah, ada banyak ciri penting yang perlu diperhatikan. Ada banyak perbedaan yang jelas dan patut diperhatikan antara sistem pendidikan dan kebijakan kepemimpinan di Madrasah-Madrasah di Indonesia dan tentu saja Kabupaten Gorontalo adalah bagian dari itu.

Posisi tertinggi di Madrasah Ibtidaiyyah Kabupaten Gorontalo adalah kepala Madrasah. Kepala Madrasah Ibtidaiyyah di Kabupaten Gorontalo biasanya berusia lebih tua dibandingkan dengan guru lainnya. Pemilihan kepala madrasah, spesialis mata pelajaran dan kepala Madrasah dilakukan secara konsisten berdasarkan senioritas serta evaluasi yang dilakukan secara berturutturut setiap tahun. Di Kabupaten Gorontalo, pelatihan dalam jabatan merupakan masalah serius. Untuk menghasilkan pemimpin Madrasah yang berkualitas, kualifikasi profesional telah diperkenalkan sebagai program nasional tetapi masih kurang dan bahkan belum sesuai dengan standar. Dalam sistem pendidikan Indonesia, ada hal lain yang perlu dicatat bahwa semua kepala Madrasah, dan guru di Madrasah umumnya adalah pegawai negeri, sisanya adalah guru kontrak dan honorer.

Peran kepala madrasah didefinisikan dengan baik dan diuraikan yang mengidentifikasi tugas yang jelas dan tepat terkait dengan peran mereka. Tanggung jawab tersebut terutama pada pelaksanaan program pendidikan yang telah ditentukan dan ditetapkan oleh Kementerian Pendidikan. Administrasi pembelajaran, menjaga disiplin, arahan semua tindakan seperti koneksi kurikuler, ko-kurikuler, ekstra-kurikuler dan suportif. Selain kepala Madrasah dan kepala Madrasah. Ada orang lain untuk menjalankan fungsi kepemimpinan di Madrasah termasuk yang merupakan wakil kepala Madrasah. Kepala Madrasah bertanggung jawab kepada otoritas kementerian agama kabupaten dan provinsi. Pimpinan Madrasah harus memastikan bahwa dengan tanggung jawab instruksional mereka harus memenuhi serangkaian peran, uraian tugas, tugas dan indikator kunci kinerja tertentu.

Kepala Madrasah Ibtidaiyyah di kabupaten Gorontalo memiliki peran mendasar untuk memodifikasi dan peningkatan kualitas Madrasah. PMA memberikan kerangka kerja sementara pimpinan Madrasah bertanggung jawab dan diharapkan untuk mematuhi persyaratan yang ditetapkan dalam peraturan tersebut. Mereka harus terbuka untuk metode kerja baru, melibatkan masyarakat 
untuk meningkatkan kemampuan di dalam dan di luar Madrasah, dan berfungsi sebagai guru dan mentor untuk mengembangkan kapasitas orang lain. Singkatnya, Kepala Madrasah Ibtidaiyyah Kabupaten Gorontalo semakin dipandang sebagai pemimpin pendidikan, terutama bertanggung jawab kepada kementerian atas kinerja peserta didik, kinerja Madrasah, dan keberhasilan penerapan sistem pendidikan.

\section{METODE}

Penelitian ini dilakukan untuk mengetahui tingkat praktik kepemimpinan instruksional kepala Madrasah di madrasah ibtidaiyyah Kabupaten Gorontalo. Desain penelitian kualitatif digunakan dan wawancara semi-terstruktur dilakukan serta pengisian angket secara online melalui google form. Studi ini mencoba untuk mengungkapkan rekognisi dan pendapat para kepala madrsah dan guru tentang kepemimpinan instruksional di madrasah Ibtidaiyyah se-Kabupaten Gorontalo. Tujuannya adalah untuk meningkatkan basis pengetahuan terkait kepemimpinan instruksional dengan menggunakan pendekatan induktif.

Pemilihan kepala madrasah ibtidaiyyah untuk penelitian ini didasarkan pada pengambilan sampel secara purposif dan kemampuan mereka untuk berbagi pengalaman mengetahui bahwa mereka memiliki banyak informasi tentang peran sebagai kepala Madrasah. 11 kepala madrasah ibtidaiyyah dipilih sebagai perwakilan dari 33 madrasah ibtidaiyyah se-kabupaten Gorontalo. Kepala Madrasah dalam penelitian ini dianggap sebagai kepala Madrasah yang cakap dan juga dianggap sebagai pemimpin yang berkinerja baik. Lebih lanjut, untuk penelitiani ini, masa kerja dan pengalaman mereka sebagai kepala Madrasah dianggap sangat berharga untuk menjawab pertanyaan yang relevan.

\section{HASIL PENELITIAN}

Kerangka konseptual mengintegrasikan dan menjelaskan secara rinci tiga dimensi utama: 1) Definisi Misi Madrasah, 2) Manajemen Program Instruksional dan 3) Promosi Madrasah. Setiap dimensi terdiri dari beberapa fungsi terkait dan dibahas secara rinci sesuai dengan data yang dikumpulkan, dianalisis, dan diinterpretasikan.

\section{Mendefinisikan Misi}

Meta-analisis literatur kepemimpinan MadrasahMadrasah mendukung pentingnya tujuan dan visi pemimpin lembaga dalam mendapatkan hasil yang baik. Dimensi pertama kepemimpinan instruksional 'Mendefinisikan Misi Madrasah' terdiri dari dua fungsi a) Membingkai Tujuan Madrasah dan b) Mengkomunikasikan Tujuan Madrasah. Dalam fungsi pembingkaian Tujuan Madrasah ini, kepala Madrasah menentukan bidang Madrasah yang akan 
ditekankan selama tahun tertentu. Fungsi kedua mengkomunikasikan Tujuan Madrasah dikaitkan dengan bagaimana kepala Madrasah berkomunikasi dan metode apa yang digunakan untuk mengkomunikasikan tujuan inti Madrasah kepada orang tua, masyarakat, guru dan peserta didik.

Terkait dengan a) Membingkai Tujuan Madrasah, wawancara mengungkapkan bahwa kepala Madrasah tidak dapat menguraikan dengan secara jelas tentang visi,misi dan tujuan mereka sendiri untuk pelaksanaan kinerja lebih lanjut. Visi, misi dan tujuan mereka terbatas pada hasil rapat setiap tahun. Mereka tidak jelas tentang tujuan dan prospek mereka sendiri. Tetapi pada saat yang sama mengenai tujuan dan sasaran yang ditentukan secara resmi dari Madrasah yang diberikan kepada mereka oleh kemeterian agama kabupaten, mereka jelas dan juga di jalur yang tepat untuk mengikutinya dengan benar dan baik. Disoroti bahwa Kementerian Agama Kabupaten dan Provinsi bertanggung jawab untuk menentukan tujuan formal Madrasah secara terpusat yang juga umumnya terbatas pada hasil rapat sebagian besar dan sangat sedikit berkenaan dengan multi-dimensi peserta didik, serta prosedur teknis pelaksanaan pembelajaran selama masa pandemic covid-19.

Fungsi kedua b) Mengkomunikasikan Tujuan Madrasah: Data dalam penelitian mengungkapkan bahwa Kepala Madrasah menjelaskan tentang cara mereka menyampaikan tujuan kepada guru dan peserta didik, mereka tidak memiliki buletin atau situs web Madrasah tetapi mereka menekankan untuk meluluskan peserta didik dalam ujian tahunan.

Kepala Madrasah yang diwawancarai tidak jelas dalam memaparkan tentang visi dan aspirasi mereka sendiri untuk Madrasah tetapi mampu menjelaskan dan menjelaskan tentang visi dan harapan resmi Madrasah dan juga dapat berkomunikasi dengan baik. Singkatnya, dalam hal penetapan tugas dan visi resmi Madrasah serta mengkomunikasikannya perlu banyak perbaikan.

\section{Mengelola Program Instruksional}

Dimensi kedua mengelola program pembelajaran yang menekankan pada manajemen dan regulasi kurikulum dan pengajaran. Ada tiga fungsi yang terlibat dalam dimensi ini: a) Pengawasan dan Pengevaluasian Instruksi, b) Pemantauan Kemajuan Peserta didik dan c) koordinasi kurikulum. Kepala Madrasah saat mempertimbangkan dimensi ini sangat memperhatikan tentang 'menangani inti teknis' Madrasah. Kepala Madrasah dan juga pemimpin Madrasah lainnya diharapkan terlibat dalam pengelolaan, pemantauan dan peningkatan instruksi dan pembelajaran.

Hasil wawancara juga menemukan bahwa pengawaan dan evaluasi instruksi dan memantau kemajuan peserta didik adalah perhatian utama kepala Madrasah dan mereka menjalankan peran ini secara terus menerus dan 
berkesinambungan. Kepala Madrasah berusaha memantau dan mengevaluasi guru dengan serius dan sistematis di madrasahnya. Kemajuan guru dan peserta didik seharusnya dinilai secara resmi dan disaksikan oleh kepala Madrasah berkali-kali dalam tahun ajaran. Kepala Madrasah mengabdikan waktunya untuk mengawasi, memantau dan mengevaluasi kinerja guru. Selain itu, kepala Madrasah memberikan dukungan yang diperlukan bagi perkembangan guru untuk meningkatkan prestasi peserta didik.

Kepala Madrasah harus mengkomunikasikan secara bersama untuk pemeriksaan dan evaluasi guru yang benar, dan mereka juga setiap hari berkeliling dengan berjalan-jalan di Madrasah untuk memperhatikan kegiatan guru khususnya tentang teknik mengajar secara informal juga. Ini juga merupakan arahan dari kemenrerian terkait agar kepala Madrasah berkeliling Madrasah setiap hari untuk menjaga disiplin dan mengamati pengajaran bahkan diperbolehkan masuk ke ruang kelas juga. Kepala Madrasah harus mendapatkan gambaran umum tentang keunggulan instruksi dalam ruang kelas dan perkembangan pembelajaran dengan mengikuti proses ini.

Mayoritas Kepala Madrasah Ibtidaiyyah di Kabupaten Gorontalo berkeliling Madrasah setiap hari untuk tujuan evaluasi formal guru dan juga untuk informal juga. Secara resmi peran ini diberikan kepada mereka. Kepala Madrasah menghabiskan waktu di ruang kelas untuk tujuan observasi pengajaran. Banyak kepala Madrasah yang menekankan bahwa mereka mampu mengukur sifat dan kualitas proses pembelajaran dan pengajaran melalui kegiatan berjalan berkeliling di Madrasah ini. Berdasarkan fakta yang dikumpulkan dan diekstraksi dari data atas dukungan, pemantauan dan pengawasan guru di Madrasah Ibtidaiyyah Kabupaten Gorontalo, jadi dapat disimpulkan bahwa kepala Madrasah adalah pemimpin yang instruksional. Indikasi tentang fungsi selanjutnya dari kepemimpinan instruksional yakni Koordinasi Kurikulum, namun sangat sedikit temuan data dalam hal ini. Data mengungkapkan bahwa kurikulum didefinisikan di tingkat pusat dan hanya diikuti di Madrasah. Pada saat yang sama, data mengungkapkan bahwa saran dari guru melalui kepala Madrasah dikumpulkan dari waktu ke waktu.

Data pendapat kepala Madrasah tentang keterlibatan langsung guru tentang masalah kurikulum masih kecil. Mayoritas kepala Madrasah Ibtidaiyyah di Kabupaten Gorontalo memiliki wakil kepala Madrasah yang menangani masalah kurikulum dan bertanggung jawab untuk itu.

\section{Membangun Iklim Madrasah yang Positif}

Dimensi ketiga terdiri: a) Perlindungan Waktu Pengajaran, b) Pengembangan Profesional, c) Menjaga Visibilitas Tinggi, d) Pemberian Insentif untuk Guru dan e) Pemberian Insentif untuk Belajar. Dimensi ketiga dengan lima 
fungsinya menekankan bahwa dalam pengembangan madrasah yang efektif selalu ada keyakinan akan perluasan yang berkelanjutan melalui fokus yang terus-menerus pada peningkatan pengajaran langsung di ruang kelas pembelajaran. Mencontohkan dan mendemonstrasikan data, kepala Madrasah Ibtidaiyyah di Kabupaten Gorontalo tidak secara langsung bertanggung jawab untuk memproteksi waktu pembelajaran tetapi mereka membantu guru mereka untuk melakukannya dengan cara multidimensi seperti mengurangi beban tambahan dengan pembagian beban kerja yang tepat dan juga dengan menghindari ko-kurikuler atau kegiatan lain selama waktu pengajaran di kelas.

Dalam hal pemberian insentif bagi guru dan pemberian insentif belajar, meskipun pendapatan Madrasah dialokasikan secara terpusat, data menunjukkan banyak contoh, dimana guru dan peserta didik diberi penghargaan oleh kepala Madrasah dengan menciptakan cara-cara kreatif yaitu melalui reward hadiah, piagam/sertifikat. Praktik-praktik ini berbeda satu sama lain dengan kepala madrasah lainnya.

Kepala Madrasah Ibtidaiyyah di Kabupaten Gorontalo tidak sepenuhnya bertanggung jawab untuk mempromosikan pendidikan profesional, peningkatan kualitas guru dan juga ini tidak mencerminkan indikator kinerja utama. Tetapi data mengungkapkan bahwa kepala Madrasah mendukung pengembangan profesional dan terindikasi dengan baik dalam data dengan memberikan mereka dalam mata pelajaran yang berbeda berdasarkan pelatihan yang berkaitan dengan pengajaran dan pembelajaran. Selain itu, studi lebih lanjut tentang guru juga dihargai oleh kepala madrasah. Oleh karena itu, dapat disimpulkan kepala madrasah menjalankan tanggung jawab ini dengan serius untuk memastikan pengembangan profesional.

\section{KESIMPULAN}

Riset ini adalah studi dalam skala kecil dan terdapat keterbatasan studi. Berdasarkan data yang dikumpulkan dan diinterpretasikan, Kepala Madrasah Ibtidaiyyah Kabupaten Gorontalo adalah pemimpin instruksional di beberapa madrasah bahkan jika mereka tidak menemukan terminologi kepemimpinan instruksional tetapi praktik yang mereka lakukan di Madrasah sebagian besar mengikuti model Hallinger \& Murphy tentang pemipin yang isntruksional. Kepala Madrasah secara berulang memulai pemantauan dan evaluasi pengajaran. Fokus pada pengembangan profesionalitas pendidik dianggap aktif. Wawancara menunjukkan bahwa kepala Madrasah melibatkan guru dalam pembelajaran profesional yang sesuai pada akhirnya akan menghasilkan perbaikan Madrasah. Meskipun mereka tidak menetapkan tujuan aktif tetapi sangat efisien mengikuti tujuan resmi yang ditetapkan oleh kementerian terkait sebagai bagian utama dari kewajiban kepemimpinan. Kepala Madrasah menghadapi beberapa masalah dalam 
peran kepemimpinan mereka saat ini. Kekhawatiran ini terkait dengan masalah kolektivisme dan kolegialitas versus kepatuhan dan kontrol. Kepala Madrasah beranggapan bahwa mereka mendapat tekanan yang sangat besar dari kewajiban pribadi dan pertanggungjawaban pengesahan Madrasah dari Kementerian terkait yakni kabupaten dan provinsi.

Di atas segalanya, dapat dikatakan bahwa kepala Madrasah yang dijadikan sumber data di dalam penelitian ini memberikan komitmen yang kuat untuk meningkatkan madrasah dengan kinerja melalui praktik kepemimpinan instruksional seperti yang diharapkan oleh Kementerian kabupaten dan provinsi.

\section{DAFTAR PUSTAKA}

Azeez, Mohd Ibrahim K., Mohammed Sani Ibrahim, and Rosemawati Mustapa. "Kompetensi Kepemimpinan Instruksional Di Kalangan Pengetua Sekolah Satu Kajian Empirikal Di Negeri Selangor." JuPiDi: Jurnal Kepimpinan Pendidikan 2.3 (2017): 1-14.

Amad, Syarwan. "Problematika kurikulum 2013 dan kepemimpinan instruksional kepala sekolah." Jurnal Pencerahan 8.2 (2014).

Damopolii, R., and A. Erwinsyah. "Gaya Kepemimpinan Transformasional Kepala Sekolah Dan Pengaruhnya Terhadap Prestasi Peserta Didik". Tadbir: Jurnal Manajemen Pendidikan Islam, Vol. 7, no. 2, Aug. 2019, pp. 86-105, doi:10.30603/tjmpi.v7i2.1111.

Djafri, Novianty. Manajemen Kepemimpinan Kepala Sekolah:(Pengetahuan Manajemen, Efektivitas, Kemandirian Keunggulan Bersaing dan Kecerdasan Emosi). Deepublish, 2017.

Domsch, G. D. A study investigating relationships between elementary principals' and teachers' self-efficacy and student achievement. Disertasi Ijazah Pendidikan, Saint Louis University, 2009.

Mulyasa, E. Manajemen Dan Kepemimpinan Kepala Sekolah, Jakarta: Bumi Aksara, 2015.

Mulyasa, E. Menjadi Kepala Sekolah Profesional dalam Konteks menyukseskan MBS dan KBK. Bandung: Remaja Rosda Karya, 2004.

Harris, A. Distributed Leadership Matter Perspectives, Practicalities, and Potentials. Thousand Oaks, California: Cor-win Sage Company, 2014.

Heck, R., \& Hallinger, P. "Testing a Longitudinal Model of Distributed Effect on School Improvemen”. Leadership Quarterly, 21, 2010.

Hermino, A. Kepemimpinan Pendidikan di Era Globalisasi. Jakarta: Pustaka Pelajar, 2014.

Karim, Mukhammad A., and Erni Rosminingsih. "Pengaruh Dimensi Kepemimpinan Instruksional Kepala Sekolah Terhadap Efikasi Diri Guru." Inspiratif Pendidikan 9.2 (2020): 18-34. 
Lakisa, N., K. Yahiji, and S. S. Posangi. "Strategi Kepemimpinan Kepala Madrasah Dan Implikasi Terhadap Peningkatkan Mutu Pembelajaran Di Madrasah Aliyah Negeri 1 Kota Gorontalo”. Irfani, Vol. 15, no. 2, Dec. 2019, pp. 59-75, doi:10.30603/ir.v15i2.1175.

Ngiode, S. "Pengaruh Kepemimpinan Kepala Sekolah, Motivasi Kerja Dan Disiplin Kerja Terhadap Kinerja Guru MTs.N Batudaa Kabupaten". Tadbir: Jurnal Manajemen Pendidikan Islam, Vol. 4, no. 2, Aug. 2016 , pp.

127-3, http://www.journal.iaingorontalo.ac.id/index.php/tjmpi/article/view/446.

Ramadhani, Annisa Fortuna. "Kepemimpinan Pendidikan” (2019): 1-133.

Sugiyono. Metode Penelitian Pendidikan Pendekatan Kuantitatif, Kualitatif, dan $R \& D$. Bandung: Alfabeta, 2015.

Sukmawati, Cucu, and Endang Herawan. "Kepemimpinan Instruksional Kepala Sekolah, Komitmen Guru Dan Mutu Kinerja Mengajar Guru.” Jurnal Administrasi Pendidikan 23, no. 2 (2016).

Sunardi, Sunardi, Piter Joko Nugroho, and Setiawan Setiawan. "Kepemimpinan Instruksional Kepala Sekolah." Equity in Education Journal 1.1 (2019): 20-28.

Usman, Husaini. "Model kepemimpinan instruksional kepala sekolah." Jurnal Cakrawala Pendidikan 34.3 (2015). 